\title{
ARBuSCULAR MYCORRHIZAL ASSOCIATIONS AND DARK SEPTATE ENDOPHYTES IN YACON (SMALLANTHUS SONCHIFOLIUS) AND A WILD RELATIVE (SMALLANTHUS MACROSCYPHUS)
}

\author{
MARIA I. MERCADO ${ }^{1,3^{*}}$, MARIA V. COLL ARÁOZ ${ }^{1}$, CELIA I. BRANDÁN DE WEHT², \\ GRACIELA I. PONESSA ${ }^{3}$ and ALFREDO GRAU ${ }^{1}$
}

\begin{abstract}
Summary: Mycorrhizal associations in Smallanthus sonchifolius (Poepp. \& Endl.) H. Robinson (Asteraceae), Yacon, an ancient Andean crop and Smallanthus macroscyphus (Baker ex Martius) A. Grau, wild yacon, a close wild relative are described for the first time. Yacon fibrous roots growing under field conditions have high levels of colonization by arbuscular mycorrhizal fungi (86 \%). Other fungi colonizing roots included dark septate endophytes (45\%) and unidentified fungi that are probably saprophytic ( $25 \%$ ) were observed. Only $9 \%$ of the samples analyzed were not colonized by any type of fungi. Glomus, Acaulospora, Scutellospora, Gigaspora and Pacispora were the main genera of arbuscular mycorrhiza identified. A similar high degree of mycorrhizal colonization was observed in Smallanthus macroscyphus, in natural populations associated with Juglans australis native forest. The high level of mycorrhizal colonization, the low number of fine absorbing roots and the large roots diameters observed, suggest that both Smallanthus species are likely dependent on mycorrhiza.
\end{abstract}

Key words: Smallanthus sonchifolius, Smallanthus macroscyphus, mycorrhizas, arbuscular mycorrhizas, dark septate endophytes.

Resumen: Micorrizas arbusculares y endófitos septados oscuros en yacón (Smallanthus sonchifolius) y un pariente silvestre (Smallanthus macroscyphus). Se describen por primera vez las asociaciones simbióticas micorrícicas en Smallanthus sonchifolius (Poepp. \& Endl.) H. Robinson (Asteraceae), yacón, un cultivo andino precolombino, y en el yacón del campo, Smallanthus macroscyphus (Baker ex Martius) A. Grau, especie silvestre estrechamente emparentada. Las raíces fibrosas de yacón creciendo en un cultivo presentaron un alto nivel de colonización por hongos micorrícicos arbusculares (86 \%). Además se observaron endófitos septados oscuros colonizando las raíces (45\%) y otros hongos no identificados, probablemente saprofíticos (25\%). Solo el $9 \%$ de las muestras analizadas no presentaba colonización. Los hongos micorrícicos arbusculares identificados correspondíeron mayormente a los géneros Glomus, Acaulospora, Scutellospora, Gigaspora y Pacispora. Ejemplares de poblaciones naturales de Smallanthus macroscyphus creciendo asociados a Juglans australis presentaron un nivel de colonización semejante. El alto nivel de colonización y las pocas raíces fibrosas observadas sugiere que ambas especies se comportan como micótrofas dependientes.

Palabras clave: Smallanthus sonchifolius, Smallanthus macroscyphus, micorrizas, micorrizas arbusculares, endófitos septados oscuros.

\footnotetext{
${ }^{1}$ Instituto de Ecología Regional (IER), Facultad de Ciencias Naturales, Universidad Nacional de Tucumán, CC34, (4107) Yerba Buena, Tucumán, Argentina.

${ }^{2}$ Cátedra de Microbiología Agrícola, Facultad de Agronomía y Zootecnia, Universidad Nacional de Tucumán, Florentino Ameghino s/n, Barrio Mercantil, El Manantial (4105), Tucumán, Argentina.

${ }^{3}$ Instituto de Morfología Vegetal, Fundación Miguel Lillo, Miguel Lillo 251. S.M. de Tucumán (4000), Tucumán, Argentina.

* Corresponding author: mainesmer@yahoo.com.ar
} 


\section{INTRODUCTION}

Plant roots interact with a wide variety of rhizospheric microorganisms, including bacteria and fungi, which greatly affect plant growth and productivity (Barea \& Jeffries, 1995; Akiyama \& Hayashi, 2002). Arbuscular mycorrhizae (AM) are the most widespread form of symbiotic associations known to occur between the roots of more than $80 \%$ of higher plants and a group of fungi that belongs mainly to order Glomerales, phylum Glomeromycota (Schüßler et al., 2001; Koide \& Mosse, 2004). In addition to the widely studied AM fungi, increased attention has recently been given to a ubiquitous group of miscellaneous fungi designated as dark septate endophytes (DSE) characterized by melanized septate hyphae and microsclerotia (Peterson et al., 2004). These fungi are frequent root colonizers of a broad range of plants in temperate and tropical habitats (Jumpponen \& Trappe, 1998) including mycorhizal macrophytes (Marins et al., 2009) and may function as mutualistic fungi (Jumpponen, 2001; Barrow \& Osuna, 2002).

Yacon, Smallanthus sonchifolius (Poepp. \& End1.) H. Robinson (Asteraceae), is an ancient Andean crop (cultivated from Colombia to NW Argentina) used for centuries by the native inhabitants as food (Fig.1 A-B). Yacon tuberous roots are rich in oligofructans (Goto et al., 1995; Lachman et al., 2003) and antioxidants (Simonovska et al., 2003; Yan et al., 1999) and are potentially useful as prebiotics, natural sweetener, functional food, and dietary supplements (Seminario et al., 2003; Genta et al., 2005; Genta et al., 2009). In the last two decades the use of yacon leaves to treat diabetes has increased. Infusions made from dry yacon leaves produce a remarkable hypoglycemic effect on normal and diabetic rats (Aybar et al., 2001). Yacon popularity has increased and it is cultivated and sold in markets of Peru, Brasil, NW Argentina, Japan, China, Corea, New Zealand, and some European countries.

Smallanthus macroscyphus (Baker ex Martius) A. Grau, is a wild species found in deciduous forests and riverbanks in Southern Bolivia and NW Argentina and is taxonomically related to yacon (Grau \& Rea, 1997) (Fig.1 C-D).

Yacon and S. macroscyphus have a large aerial biomass of leaves and stems (Kortzart Gonzales, 2009) and subterranean organs consisting of rhizomes with large adventitious tuberous roots and few fibrous absorbent roots (Machado et al., 2004; Coll Aráoz et al., 2008). Plant species with root systems of this nature are frequently dependent on mycorrhizal fungi for adequate mineral and water uptake (Varma, 1999; Jakobsen et al., 2003). Our main objective was to determine the presence of mycorrhizal fungal symbiotic interactions as well as spore populations in rhizosphere soils in yacon under cultivated conditions and S. macroscyphus in its natural habitat. A second objective was to screen roots for other fungal endophytes.

\section{Materials and Methods}

\section{Sample collection}

Soil samples, roots and rhizomes were collected from ten individuals of yacon randomly selected cultivated at Horco Molle University Center (600 masl, $27^{\circ} \mathrm{S}, 65^{\circ} \mathrm{W}$, Tucumán, Argentina) in April 2007 at the flowering stage. Ten individuals of $S$. macroscyphus in flowering stage growing in a Juglans australis dominated forest were collected in February of 2008 in Rearte, Trancas, Tucumán, Argentina. Voucher specimens of both species were deposited in the herbarium of "Fundación Miguel Lillo", San Miguel de Tucumán, Tucumán, Argentina LIL Mercado and Ponessa s/ $\mathrm{n}^{\circ}$ LIL 607175, 607375. Roots and rhizomes from both species were treated individually and were carefully cleaned and preserved in FAA (formalin: glacial acetic acid: 70\% ethanol, 5:5:90) until processing. Three samples of rhizosphere soil (1 Kg each) were collected from both localities (Horco Molle and Rearte). From each sample 100 g were dried at $65^{\circ} \mathrm{C}$ for three days until constant weight and passed through a $2 \mathrm{~mm}$ sieve and used for physical chemical analyses. The rest of the soil samples were used for isolation of fungal spores.

\section{Soil properties of the study sites}

The soils at the study sites were classified as Ustifluvens (Mon \& Suayter, 1972; Toselli et al., 1975), slightly acid and very rich in available nutrients and organic matter, particularly Rearte (Table 1). 
M. I. Mercado et al. - Mycorrhizal associations in Smallanthus species

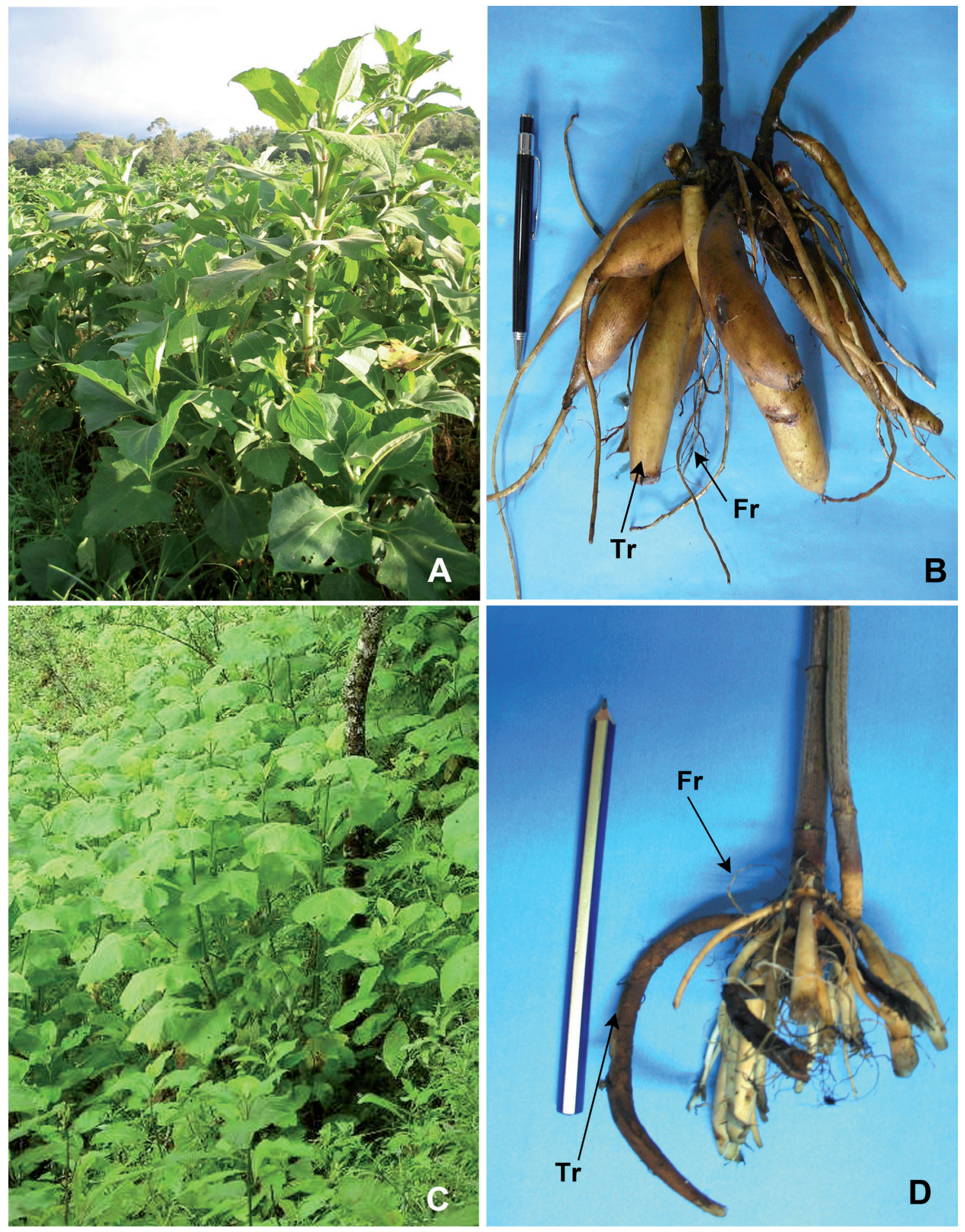

Fig.1. General aspect, panels $\mathbf{A}$ and $\mathbf{C}$ and detail of tuberous $(\mathrm{Tr})$ and fibrous $(\mathrm{Fr})$ roots, panels $\mathbf{B}$ and $\mathbf{D}$..of S. sonchifolius.. S. macroscyphus respectively. 
Bol. Soc. Argent. Bot. 48 (2) 2013

Table 1: Physical chemical analysis of soils in two regions of the Yungas. Tucuman, Argentina. 2008.

\begin{tabular}{|c|c|c|c|c|c|c|c|c|c|}
\hline \multirow{2}{*}{ Soil sample } & \multicolumn{3}{|c|}{ Granulometry } & \multirow{2}{*}{ Texture } & \multirow{2}{*}{$\mathrm{pH}^{1}$} & \multirow{2}{*}{$\begin{array}{l}\text { Organic } \\
\text { mater }{ }^{2} \%\end{array}$} & \multirow{2}{*}{$\begin{array}{l}\mathrm{N}^{3} \\
\%\end{array}$} & \multirow{2}{*}{$\begin{array}{c}\mathrm{P}^{4} \\
\mathrm{ppm}\end{array}$} & \multirow{2}{*}{$\begin{array}{c}\mathrm{K}^{5} \\
\text { me. } 100 \mathrm{~g}^{-1}\end{array}$} \\
\hline & S \% & s $\%$ & C \% & & & & & & \\
\hline $\begin{array}{l}\text { Horco Molle } \\
\text { (S. sonchifolius) }\end{array}$ & 58.1 & 33.1 & 8.8 & Sandy loam & 5.6 & 5.33 & 0.31 & 62.5 & 0.86 \\
\hline $\begin{array}{l}\text { Rearte } \\
\text { (S. macroscyphus) }\end{array}$ & 71.9 & 24.2 & 3.9 & Sandy loam & 6.6 & 12.23 & 0.63 & 46.8 & 1.57 \\
\hline
\end{tabular}

References: S, sand; s, silt; C, clay; (1) potentiometry ratio soil: water 1:2.5; (2) Walkey-Black method; (3) total nitrogen Kjeldahl method; (4) available phosphor Bray-Kurtz method; (5) Morgan method.

\section{Assessment of roots and rhizomes for colonization}

Due to the limited availability of fibrous roots in each plant, particularly $S$. macroscyphus (Coll Aráoz et al., 2008), a composite sample was prepared from the ten individuals of each specie to estimate AM and DSE colonization. Fibrous roots fixed in FAA were cleared in $10 \% \mathrm{KOH}$ solution at $80{ }^{\circ} \mathrm{C}$, acidified with $\mathrm{HCl} 5 \%$ and stained with Gueguén (lactic acid: 100 g, Trypan blue: 0,1 g, Sudan IV Or: 0,1 $\mathrm{g}$, and Iodine tincture: 10-30 droplets) (Verna \& Herrero, 1952). Roots that remained dark after clearing were bleached with an alkaline solution (169 ml distilled water: $3 \mathrm{~mL} \mathrm{NH}_{3}$ : 20 $\mathrm{mL} \mathrm{H}_{2} \mathrm{O}_{2}$ ) before staining. Four replicates each consisting of twenty five stained fibrous root 1 $\mathrm{cm}$ long were examined for each species. Root segments were mounted on microscope slides in lactoglycerol and examined for fungal structures. A root segment was considered as AM positive if it showed extraradical mycelium, intraradical hyphae, arbuscules or vesicles and DSE positive if pigmented dematiaceous septate hyphae or microsclerotia were observed. Other unidentified fungal structures where classified as "other". Percent of root colonization by AM fungi or DSE was estimated according to the magnified intersect method (McGonigle et al., 1990).

The rhizomes of the ten individuals of both species were cleared and bleached in an identical manner as the roots and analyzed separately. After clearing they were free-hand sectioned, stained with Gueguen, mounted in lactoglycerol and examined with a compound light Karl Zeiss Axiostar plus microscope with a Canon compact digital camera, model PowerShot A 620 IS M52 (O) 12.1 Megapixel, for assessment of fungal colonization.

\section{Isolation and identification of spore population}

Three dry soil samples from each species weighing $100 \mathrm{~g}$ were analyzed and considered as three replications. The spore population was assessed by the wet sieving and decanting method (Gerdeman \& Nicolson, 1963) followed by centrifugation on a $80 \%$ sucrose gradient (Sieverding, 1991). All the spores were isolated from the supernatant and extracted with a brush into a watch glass with a small quantity of water. Intact fungal spores were mounted in polyvinyl alcohol-lactoglycerol with Melzer's reagent and were identified using INVAM keys (http://www. invam.caf.wvu.edu) and Schenck \& Perez (1990) by Dra. Marta Cabello, Instituto Spegazzini, Facultad de Ciencias Naturales y Museo, La Plata, Argentina. Because of the low abundance of certain morphotypes, species identification was performed only with spores in good condition (no sign of degradation or parasitism) and some could only be identified to genus.

\section{Results}

A high level of mycorrhizal colonization was observed with simultaneous occurrence of AM fungi and DSE in most cases. AM associations were observed in $75 \%$ of the samples of $S$. macroscyphus and $82 \%$ of the samples of S. sonchifolius. DSE colonized more than $40 \%$ of the samples in both species. The extent of unidentified fungal structures colonization, probably saprophytic fungi, ranged between $5 \%$ for S. macroscyphus and $25 \%$ for S. sonchifolius. Only $9 \%$ to $11 \%$ of the samples analyzed were not colonized by any type of fungal structures (Fig. 2).

In both species AM associations were typified 
as Arum-type (Fig. 3 A, B) characterized by root entry with formation of an appressorium (Fig. $3 \mathrm{G}$ ), intercellular hyphal growth in the root cortex, with short lateral branches into cortical cells forming arbuscules (Fig.3 A, B,C), and vesicles filled with several types of lipid droplets (Fig. 3 D, E). On the other hand DSE were frequently characterized by brown, narrow, septate, runner hyphae commonly occurring on the root surface and typically running parallel to the long axis of roots (Fig. 3A, G). Individual hyphae sometimes grew along the furrows between adjacent epidermal cells and colonized roots intercellularly. Penetration through root hairs was not observed. Once in the epidermis, hyphae grew from cell to cell within the epidermis parallel to the main axis of the host root, causing no distortion of host root. At regions the hyphae penetrated the cortical cells filling each cell with microsclerotia (Fig. 3 F). The root stele was not colonized in any of the roots that had DSE fungal associations and there was no evidence of damage to host root tissues arising from fungal colonization.

The rhizome samples analyzed were not colonized by any fungal structure.

In the rhizospheric soil samples of both species, five AM fungal genera were identified on the basis of spore morphology and Melzer's reaction: Glomus, Acaulospora, Scutellospora, Gigaspora and Pacispora. In S. sonchifolius rhizospheric soil these included, four morphotypes belonging to Acaulospora (A. scrobiculata, A. elegans, A. denticulata and Acaulospora sp.), two Glomus (G. clarum and Glomus sp.) two Scutellospora (S. pellucida and Scutellospora sp.), two Gigaspora and one Pacispora morphotypes. In $S$. macroscyphus rhizospheric soil three Acaulospora (A. scrobiculata, A. foveata and A. bireticulata), five Glomus (G. clarum, G. etunicatum, G. mosseae, Glomus sp. ${ }^{1}$ and Glomus sp. ${ }^{2}$ ), two Scutellospora, one Gigaspora and one Pacispora morphotype were observed.

\section{Discussion}

Smallanthus sonchifolius and S. macroscyphus show high productivity and development under cultivation and in its natural habitat respectively (Grau \& Rea, 1997; Seminario et al., 2003; Kortzart Gonzales, 2009). Natural mycorrhizal

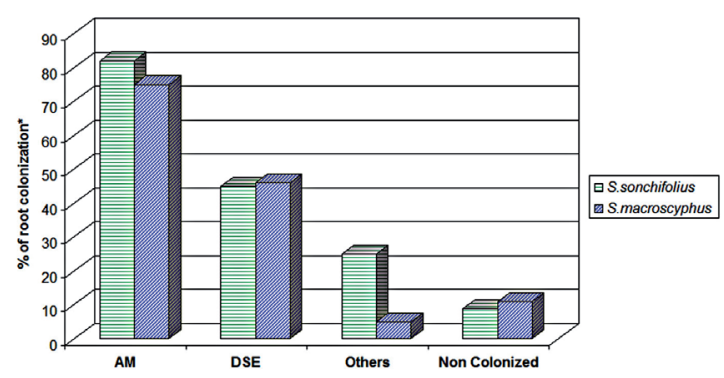

Fig. 2. Ratio of different types of root-associatedfungi colonizing Smallanthus sonchifolius and $S$. macrocyphus fibrous roots. References: Percent of root colonization by AM fungi, DSE or other unidentified fungi (Others) was estimated according to the intersect method of McGonigle et al., 1990. *Detection of AM, DSE and other unidentified fungi is expressed as percentages for each fungus in relation to the total number of samples observed $(n=100)$.

symbiotic associations may enhance plant growth and production through improved access to mineral and water resources, among others beneficial effects (Finlay, 2004).

Simultaneous occurrence of AM fungi and DSE was observed in both species. Simultaneous colonization by AM and DSE was previously reported for other medicinal and aromatic plants (Jupponen \& Trappe, 1998; Muthukumar et al., 2006). DSE are common plant colonizers in temperate and tropical habitats (Jumpponem \& Trappe, 1998), while Arum-type AM seems to be abundant among herbaceous plants such as yacon and Paris-type AM seems to be more frequently found among trees (Muthukumar et al., 2006).

According to Brundrett (2004, 2009), the high level of mycorrhizal colonization associated with a poorly developed absorbing root system with large roots diameters and a large biomass conformed by tuberous roots, leaves and aerial stems, suggests a mycotrophic relationship dependent on mycorrhiza. All this characteristic of both Smallanthus species (Machado et al., 2004; Coll Araoz et al., 2008; Kortzart Gonzales, 2009).

Rhizomes of obligate mycorrhizal plant species such as orchids and Psilotum can be colonized by AM (Brundett, 2002). These associations were not observed in any of the Smallanthus species under study. 
Bol. Soc. Argent. Bot. 48 (2) 2013

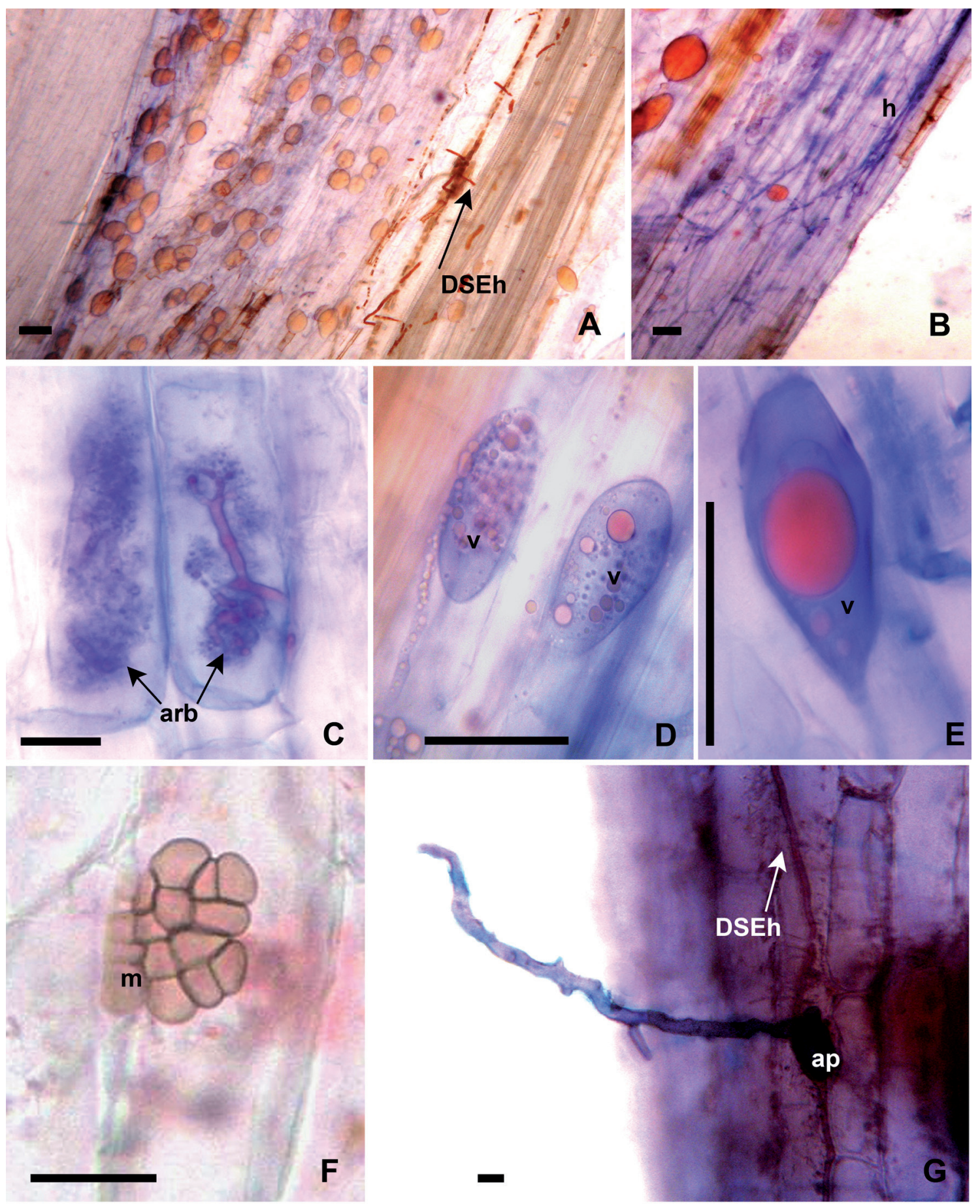

Fig. 3. Light micrographs. A and B: Arbuscular mycorrhizal Arum-type hyphae (h), vesicles (v) and dark septate endophytic intraradical septate hyphae (DSEh) stained with Gueguén. Scale bar $=100 \mu \mathrm{m}$. C: AM arbuscule (arb). D and E: AM vesicle (v) with fatty acids stained in red. F: DSE Microsclerotia (m). G: Appressorium (ap) and DSE hyphae (DSEh) on the root surface of Smallanthus sonchifolius. Scale bar = $50 \mu \mathrm{m}$. 
Further studies are ongoing to characterize the AM and DSE involved in this mycorrhizal association in order to investigate the effect of nutrition mediated by these fungi in the production of secondary metabolites and determine their potential promoting growth in both Smallanthus species.

\section{ACKNOWLEDgemenTS}

Dra. Marta Cabello, Instituto Spegazzini, Fac. Ciencias Naturales y Museo, La Plata, Argentina contributed to the identification of fungi spores. Dr. R. Larry Peterson made valuable improvements to the first draft. Funding: This research was supported by ANPCyT (Grant PICTO 2004-503), CIUNT A26/403 and CONICET from Argentina.

\section{REFERENCES}

AKIYAMA, K. \& H. HAYASHI. 2002. Arbuscular mycorrhizal fungus-promoted accumulation of two new triterpenoids in cucumber roots. Biosci. Biotechnol. Biochem. 66: 762-769.

AYBAR, M.J.,A.N.S. RIERA, A. GRAU \& S.S. SANCHEZ. 2001. Hypoglycemic effect of the water extract of Smallantus sonchifolius (yacon) leaves in normal and diabetic rats. J. Ethnopharmacol. 74: 125-132.

BAREA, J.M. \& P. JEFFRIES. 1995. Arbuscular mycorrhizas in sustainable soil plant systems. In: VARMA A. \& B. HOCK (eds.), Mycorrhiza: structure, function, molecular biology and biotechnology, pp. 521-560. Springer-Verlag, Berlin.

BARROW, J.R. \& P. OSUNA. 2002. Phosphorus solubilization and uptake by dark septate fungi in fourwing saltbush, Atriplex carescens (Pursh) Nutt. J. Arid Environ. 51: 449-459.

BRUNDRETT, M.C. 2002. Coevolution of roots and mycorrhizas of land plants. New Phytol. 154: 275304.

BRUNDRETT, M.C. 2004. Diversity and classification of mycorrhizal associations. Biol. Rev. 79: 473-495.

BRUNDRETT, M.C. 2009. Mycorrhizal associations: the web resource. http://mycorrhizas.info. [Acceso: 10 Julio 2012].

COLL ARAOZ, M.V., M.I. MERCADO, A. GRAU \& G.I. PONESSA. 2008. Morfología y anatomía foliar, caulinar y radicular de Smallanthus macroscyphus (Asteraceae). Lilloa 45: 23-33.

FINLAY, R.G. 2004. Mycorrhizal fungi and their multifunctional roles. The Mycologist 18: 91-96.
GENTA, S., W.M. CABRERA, A. GRAU \& S.S. SANCHEZ. 2005. Subchronic 4-month oral toxicity study of dried Smallanthus sonchifolius (yacon) roots as a diet supplement in rats. Food Chem. Toxicol. 43: 1657-65.

GENTA, S., W.M. CABRERA, N. HABIB, J. PONS, I.M. CARILLO, A. GRAU \& S.S. SÁNCHEZ. 2009. Yacon syrup: beneficial effects on obesity and insulin resistance in humans. Clin. Nutr. 28: 182-187.

GERDEMANN, J.W. \& T.H. NICOLSON. 1963. Spores of mycorrhizal Endogone species extracted from soil by wet sieving and decanting. Trans. Br. Mycol. Soc. 46: 235-244.

GOTO, K., K. FUKAI, J. HIKIDA, F. NANJO \& Y. HARA. 1995. Isolation and structural analysis of oligosaccharides from yacon (Polymnia sonchifolia). Biosci. Biotechnol. Biochem. 59: 2346-2347.

GRAU, A. \& J. REA. 1997. Yacon, Smallanthus sonchifolius (Poepp. \& Endl.) H. Robinson. In: HERMANN M. \& J. HELLER (eds.), Andean roots and tuberous roots: Ahipa, Arracacha, Maca and Yacon. Promoting the conservation and use of underutilized crops, pp. 199-256. IPK, Gatersleben/ IPGRI, Rome.

JAKOBSEN, I., S.E. SMITH \& F.A. SMITH. 2003. Function and diversity of arbuscular mycorrhizae in carbon and mineral nutrition. In VAN DER HEIJDEN M.G.A. \& I.R. SANDERS (eds.), Mycorrhizal Ecology, pp. 75-92. Springer. Berlin.

JUMPPONEN, A. 2001. Dark septate endophytes are they mycorrhizal? Mycorrhiza 11: 207-211.

JUMPPONEN, A. \& J.M. TRAPPE. 1998. Dark septate endophytes: a review of facultative biotrophic rootcolonizing fungi. New Phytol. 140: 295-310.

KOIDE, R.T. \& B. MOSSE. 2004. A history of research on arbuscular mycorrhiza. Mycorrhiza 14: 145-163.

KORTZART GONZALES, A. M. 2009. Fisiología y perfil químico de las sustancias de reserva en el género Smallanthus (Asteraceae). Tesis Doctoral. Universidad Nacional de Tucumán, Facultad de Ciencias Naturales e Instituto Miguel Lillo. Tucumán, Argentina. pp. 70.

LACHMAN, J., E.C. FERNÁNDEZ \& M. ORSÁK. 2003. Yacon [Smallanthus sonchifolia (Poepp. \& Endl.) H. Robinson] chemical composition and use a review. Plant Soil Environ. 49: 283-290.

MC GONIGLE, T.P., M.H. MILLER, D.G. EVANS, G.L. FAIRCHILD \& J.A. SWAN. 1990. A new method which gives an objective measure of colonization of roots by vesicular arbuscular mycorrhizal fungi. New Phytol. 115: 495-501.

MACHADO, S.R., D.M.T. OLIVEIRA, M.R. DIP \& N.L. MENEZES. 2004. Morfoanatomia do sistema subterrâneo de Smallanthus sonchifolius (Poepp. \& 
End1.) H. Robinson (Asteraceae). Revista Brasil. Bot. 27: 115-123.

MARINS, J.F., R. CARRENHO \& S.M. THOMAZ. 2009. Occurrence and coexistence of arbuscular mycorrhizal fungi and dark septate fungi in aquatic macrophytes in a tropical river-floodplain system. Aquatic Bot. 91: 13-19

MON, R. \& L. SUAYTER. 1972. Geología de la Sierra de San Javier (Provincia de Tucumán), Argentina. Acta Geológica Lilloana 12: 155-168.

MUTHUKUMAR, T., M. SENTHILKUMAR, M. RAJANGAM \& K. UDAIYAN. 2006. Arbuscular mycorrhizal morphology and dark septate fungal associations in medicinal and aromatic plants of Western Ghats, Southern India. Mycorrhiza 17: 11-24.

PETERSON, R.L., H.B. MASSICOTE \& L.H. MELVILLE. 2004. Dark septate fungal endophytes. In P.B. CAVERS (ed.), Mycorrhizas: Anatomy and cell biology, pp. 145-153. NRC. CNRC, Ottawa.

SCHENCK, N.C. \& Y. PEREZ. 1990. Manual for the identification of Mycorrhizal Fungi. Synergistic Publications, Gainesville.

SCHÜßLER, A., D. SCHWARZOTT \& C. WALKER. 2001. A new fungal phylum, the Glomeromycota: phylogeny and evolution. Mycol. Res. 105: 14131421.

SEMINARIO, J., M. VALDERRAMA \& I. MANRIQUE. 2003. El Yacón: fundamentos para el aprovechamiento de un recurso promisorio. 1 ed. Centro Internacional de la Papa (CIP). Universidad Nacional de Cajamarca, Agencia Suiza para el Desarrollo y la Cooperación (COSUDE), Lima.

SIEVERDING, E. 1991. Vesicular-arbuscular mycorrhiza management in tropical agrosystems. Deutsche GTZ GmbH. Eschbom.
SIMONOVSKA, B., I. VOVK, S. ANDRENSEK, K. VALENTOVÁ \& J. ULRICHOVÁ. 2003. Investigation of phenolic acids in yacon (Smallanthus sonchifolius) leaves and tubers. J. Chromatogr. A. 1016: 89-98.

TOSELli, A. J., M. GODEAS \& J.N. ROSSI DE TOSELLI. 1975. Contribución al conocimiento petrológico del metamorfismo esquistoso de la Sierra de San Javier, Provincia de Tucumán, Argentina. Revista de la Asociación Argentina de Mineralogía, Petrología y Sedimentología 6: 103-133.

VARMA, A. 1999. Function and Application of Arbuscular Mycorhizal Fungi in Arid and SemiArid Soils. In VARMA, A. \& B. HOCK (eds.), Mycorrhiza, structure, function, molecular biology and biotechnology, pp: 521-556. 2nd. ed., Springer, Berlin.

VERNA, L.C. \& F.J. HERRERO. 1952. Micología. Morfología, biología y experimentación. El Ateneo. Bs. As.

YAN, X., M. SUZUKI, M. OHNISHI-KAMEYAMA, Y. SADA, T. NAKANISHI \& T. NAGATA. 1999. Extraction and identification of antioxidants in the roots of yacon (Smallanthus sonchifolius). J. Agric. Food Chem. 47: 4711-4713.

Recibido el 12 de abril de 2012, aceptado el 1 de marzo de 2013. 